\title{
Pre-Service Science Teachers' Training: The Case of Colleges of Education in Nigeria
}

\author{
Jacob Kola Aina \\ Physics Department, College of Education (Technical.), Lafiagi, Nigeria \\ Email: akoja64@gmail.com
}

Received 28 August 2014; revised 8 October 2014; accepted 10 November 2014

Copyright (C) 2014 by author and OALib.

This work is licensed under the Creative Commons Attribution International License (CC BY). http://creativecommons.org/licenses/by/4.0/

\section{(c) (i) Open Access}

\begin{abstract}
Colleges of Education are teacher training institutions established to train teachers for primary and junior secondary schools in Nigeria. Research shows that science teachers trained in these colleges are not performing well in classrooms after their graduation. This is due to problems associated with Colleges of Education such as lack of science equipment, bad leadership, lack of committed lecturers and bad admission policy. These problems make teachers trained in these colleges to be incompetent in teaching science. The resultant effect of this is poor students' academic performances in science subjects both in primary and secondary schools. The paper suggested some recommendations for stakeholders in education to solve the problems.
\end{abstract}

\section{Keywords}

Science Teacher, Incompetent, College of Education, Teacher Education

Subject Areas: Education, Statistics

\section{Introduction}

Colleges of Education are teachers' training institutions established to meet the need of shortage of teachers in Nigerian schools. Teacher education is a veritable tool towards educational development [1]. This is the reason there is a clear objective for it in National Policy on Education (NPE) by the Federal Government of Nigeria. For clear understanding, according to [2], the objectives are as follow:

- to produce highly motivated, conscientious and efficient classroom teachers for all levels of our education system;

- to encourage further, the spirit of enquiry and creativity in teachers;

- to help teachers to fit into the social life of the community and society at large and to enhance their commitment to national objectives;

- to provide teachers with the intellectual and professional background adequate for their assignment and to 
make them adaptable to any changing situation, not only in the life of their country, but in the wider world; and

- to enhance teachers commitment to the teaching profession.

The quality of teachers is dependent on their preparation for professional role as distinct practitioners [3]. Quality teachers are very important to the success of any educational system and to a greater extent of the success of any nation. [4] is in support of this posited that, the quality of any educational system depends on the quality of teachers' qualifications and competency.

The efforts of both Phelp-stroke and Ashby Commission in 1925 and 1959 respectively cannot be forgotten in a moment when we talk about teachers' education in Nigeria. Recommendation of Ashby commission gave birth to Advance Teachers College for a two years Grade I teachers training programme [5]. It was this two years teachers' programme that was later changed to three years programme in Colleges of Education leading to the award of Nigerian Certificate in Education (NCE). This commission also recommended National Teacher Institute and more Universities for the nation.

This review is on the Science teachers' programme of Colleges of Education based on personal experience as an academic staff in one of these colleges for over 20 years. The establishment of Colleges of Education is good and it has really helped educational system of Nigeria in many ways. However, the good story of Colleges of Education in Nigeria has become history based on what is happening in these schools presently and the type of teachers they are producing. Therefore this review will look at the problems of NCE Science teachers' programme in Nigeria and its implications for the nation.

\section{Problems of Pre-Service Science Teachers in NCE Programme}

There are many problems militating against training quality science teachers in Colleges of Education in Nigeria. These problems are multi-dimensional and are interwoven in such a way that an attempt to solve one may create another. This is because the problems generically belong to a single "mother" which is called corruption. Corruption has been institutionalized in Nigeria [6]. Therefore any attempt to remove any of the problems without capturing and exterminate corruption from the system may be a child play. Let us consider these problems one by one.

\subsection{Lack of Science Teaching Equipment}

It is only in Nigeria science is learnt without science equipment. A tour of science laboratories in Colleges of Education in the country will convince any one of the truth that, there is a dearth of science equipment in our colleges of education. Supplies of science equipment by the government are inadequate. Even where money is made available for any of these materials; wrong ones are bought or not even bought at all. Sometimes the building of laboratory and the supply of science equipment is done by the member of college Governing Council. In that case, where they failed to supply good materials or not even supply at all, there is nobody to challenge them. For this reason many students graduated as science teachers without knowing more than $95 \%$ of science equipment he or she is going to be teaching. Such teachers will end up misleading their pupils or students as most of them are teaching in secondary schools. The end result is poor academic performance of students in national and state examination. [7] has rightly observed that adequate provision of laboratory facilities plays a significant role in boosting students' achievement in Physics. The use of appropriate teaching equipment and teaching method is critical to the successful teaching and learning of Physics [8]. According to [9], insufficient resources for the teaching and learning of science constitute a major cause of student underachievement. [10] said because of inappropriate equipment, limited time allocated for the topic and poor laboratory conditions, teachers teach Physics anyhow and anywhere.

Teacher is very important to students' academic success. Teachers are the facilitators who are to impact on students the concepts expected to be learnt [11]. Teachers are the most important factor in the effectiveness of schools and in the quality of a child's education [12]. Therefore teachers' education at all level must not be tampered with as the case of Colleges of Education. The right materials to train science teachers must be made available in other not to jeopardise our children education.

\subsection{Lack of Visionary Leaders}

Most leaders in Colleges of Education are without educational vision. Most Provosts of Colleges of Education 
came into the office to make money not to better teachers' education. Similarly, the Governing Council of most colleges are group of thieves who came into Colleges of Education to steal money meant for academic purpose. I have once written on the evil doing of these Governing Councils in my paper on "Repositioning science education in Nigerian Colleges of Education through public-private partnership". In this paper I said most members of this Governing Council have turned their colleges to gold field where they make fortune against the purpose of their appointments [13]. Most of these leaders are not sensitive to the needs of the students as long as they are able to loot college treasury without check. The only time they are sensitive is when any pressure group within the system want to check their excesses. They lower admission requirements so that they could get more students to pay more money to steal. [14] had many years back cried over the lowering of admission requirements of students into Colleges of Education in Nigeria. Many of the graduates of Colleges of Education are so poor academically when you see them in classrooms that you wonder if they ever attended primary school not to talk of College of Education. These are the kind of teachers we have and we are talking about scientific and technological breakthrough.

Most Provosts and the Governing Council of our colleges do not value professional development of their staff. They often turned down any request by the academic staff to attend conference, seminar or workshop because of money. They clamp down lecturers who are willing to go on further studies because of any financial assistance they would render to such staff. The effect of all these would be on the teachers in training.

\subsection{Lack of Committed Lecturers}

Science teachers' education depends much on the quality of the academic staff of the institutions. Lecturers in Colleges of Education today are not as committed as those in the past years. The value for money and wealth has taking over their attention and time for research. That is why you can see a lecturer using a lecture note for more than three years without updating the note. They lack the current content knowledge of their courses. Content knowledge is an indicator of teachers' qualifications. If teachers are not sound in the content of what he or she teaches, there will be deficiency in both quality of learning and students' academic performance [15]. Teachers with strong content knowledge may teach in a more interesting and dynamic way whilst those with little content knowledge may shy away from the more difficult aspects of the subject, or approach their teaching in a didactic manner [16]. According to [17], there is the danger of students being misinformed or misled by a teacher who has little knowledge about the subject matter. What can we say about the pedagogical skill of some lecturers? Many are so poor in instructions and teaching method in such a way that one doubts their certificates. [18] found that pedagogical studies enable teachers to harmonize the minds and emotions of their students in class and result into higher academic achievement.

\subsection{Poor Professional Development}

Professional development is a conscious and systematic steps to ensure teachers up-grading and continuous selfimprovement [4]. According to [19], professional development is the development of a person in his or her professional role. Professional development is very important for all science teachers because of its numerous benefits to both the lecturers and the student teachers. [4] said professional development enhances and improve teachers teaching skills. Through professional development practicing teachers can upgrade their content knowledge and teaching skills; it helps to adjust to the introduction of new curricula, new research finding on teaching and learning [20].

Many lecturers have not attended any workshop, conference and seminar for the past five years and they are very comfortable with it. A teacher who has not attended conference or seminar on his or her field would rely on textbooks that have been written decades ago. Science is dynamic not static it changes every day and the only way to keep informed of the changes is through seminars, conferences, workshops and publications. Many are lazy and they cannot read journals neither could they write articles to be published in their fields. A lecturer that cannot write paper for publication will definitely not be interested in reading articles published by others. Lecturers are interested in producing hand out they will sell to their students. Some remained stagnated in a rank for a long period without promotion because they failed to upgrade their certificates.

It will be very strange that some lecturers are not computer literate and they are very comfortable. Those who are computer literate cannot sacrifice their money to buy computer/laptop for themselves. Technology has been integrated into science teaching because of its immense benefits. There are so many topics and concepts that 
cannot be effectively demonstrated by the lecturers without the use of modern technologies. For instance, in Physics and Chemistry, chain reaction and some chemical reaction are very risky to be demonstrated in the classroom. Such reactions can be demonstrated using computer educational software or simulation [21]. A teacher that cannot operate a computer or who can operate but don't have a computer system of his or her own would not be able to teach these effectively. The implications of the aforementioned problems are too great on the teachers on training and on primary and post-primary students they will be teaching in future.

\subsection{Bad Admission Policy}

Gone are the days when admission into tertiary institution was by merit. Admission into Colleges of Education is no longer by merit but by whom you know [13]. Many things are wrong with admission policy of Colleges of Education. There are many students who had problem with their secondary school results yet they are admitted because they have "godfather" somewhere in the system. On the other hand, many with poor secondary school results are admitted because the school need students to pay fees for financial gain for the college. In this case, they are compromising quality for quantity [14]. Today, as an insider I can boldly say more than $50 \%$ of the students admitted have no good secondary school results. Sometimes students who have been admitted to read Physics have not passed Physics in secondary school. How can one explain that teachers who will teach a subject have not passed the subject themselves? This is ridiculous and shameful.

\section{Implications}

All the problems highlighted above have a great implication on our educational system because anything that affects teacher is affecting the whole educational system. These problems leads to production of poor teachers and poor students' academic performance in both primary and secondary schools in Nigeria.

Studies have revealed that most Nigerian teachers are not effective in classrooms due to many reasons. [23] had once observed low rating of teachers in Nigeria due to inadequate manpower in her educational system as a result of lack of qualified teachers. Professor Peter Okebukola in [23] was concerned that, most graduate teachers are inadequately exposed to teaching practice while many of them cannot communicate effectively in English. In a related issue [5] said teacher education programmes have been deficient in providing teachers with intellectual and professional background adequate for their assessment in the nation. Many teachers lacked teaching experience, teach science in abstraction, lacked adequate knowledge of subject matter and the competence to deliver [24] [25]. [26] said teacher training institutions in Nigeria are to be blamed for producing teachers that are inadequate in terms of knowledge of subject matter and pedagogical skills.

The cry of stakeholders in education in Nigeria now is poor academic performance of students in national examination. The results of Senior Secondary School Certificate Examination (SSSCE) in Nigeria are worrisome. Yes, it should not be a strange thing because we do not expect students to be academically better than their teachers. When teachers are not good the students too will be bad.

[27] believed that causes of students' mass failure in senior secondary Chemistry Examination include teacher's methodology and the inability of students to perform enough practical before their examination. According to [28], lack of qualified teachers, lack of facilities and poor teaching method are factors to be considered when it comes to student performance in science. This author underscored the importance of teacher in science learning and said the success of any science education programme depends to a large extent on the teacher. [29] posited that inadequate teacher qualifications as well as possession of below standard of pedagogical content knowledge by teachers are problems of poor performance in Physics.

Table 1 shows students performances in three science subjects in SSSCE in Nigeria for five years. The table indicates poor performance of students in the three science subjects with the performances in Biology the poorest.

\section{Conclusion and Recommendations}

Highlight of this paper has shown that the current NCE programme in Nigerian Colleges of Education is defective and cannot produce the quality science teachers needed for the scientific and technological growth of this age. Corruption has been seen as the major problem of teacher training programme in Colleges of Education. Science equipment meant for effective training of science teachers is not available in the Colleges of Education. Lecturers in the colleges are not committed enough to their responsibility which affected professional development 
Table 1. Science students’ performances in SSSCE from 2005 to 2009.

\begin{tabular}{cccc}
\hline Year & Biology \% pass at grade $\mathrm{A}_{1}-\mathrm{C}_{6}$ & Chemistry \% pass at grade $\mathrm{A}_{1}-\mathrm{C}_{6}$ & Physics \% pass at grade $\mathrm{A}_{1}-\mathrm{C}_{6}$ \\
\hline 2005 & 35.74 & 50.94 & 41.50 \\
2006 & 35.61 & 50.95 & 43.84 \\
2007 & 33.57 & 45.96 & 58.05 \\
2008 & 33.94 & 44.44 & 48.26 \\
2009 & 33.87 & 45.97 & 43.56 \\
\hline
\end{tabular}

Source: [22].

of some of these lecturers. The result of these problems is that NCE science teachers are ineffective in teaching science and therefore should not be relied upon for science teaching in high classes. They should also be under senior and mature science teachers even in the lower classes. In view of this conclusion the following recommendations are hereby suggested:

Colleges of Education need a general overhauling. Both the management and the academic units of the colleges must be thoroughly overhauled to ensure only those who are suitable for the system remains. Any management member who is finding guilty of corruption should be dealt with while academic staff who fails to develop should be asked to find another job.

Governing Council of each college should be seriously monitored by the government by ways of checking their excesses. Appointment of members of this Council should be only those who have qualifications related to teachers' education. Politicians who know nothing about education should not be appointed as member of Governing Council of Colleges of Education.

Government should make it mandatory for the management of every College of Education to set aside fund for professional development every year. Each Provost of the colleges should have a list of academic staff that are to either go to conferences or further studies every year. Any staff who fails to make use of such available opportunity should be seriously dealt with.

Computer literacy is a must for all academic staff and the government should enforce it upon the college management to be serious about it. All lecturers must have a functional laptop.

We should go back to the old method of admitting students into schools that was based on merit. No student should be admitted without good secondary school result. Students must have good grade in the subject he or she is applying for.

Government should be ready to finance all Colleges of Education. The method of using money paid by the students to finance the college is the root of admission problem. The college should only admit students who are qualified without thinking about the money these students will pay to the college.

\section{References}

[1] Akindutire, I.O. and Ekundayo, H.T. (2012) Teacher Education in a Democratic Nigeria: Challenges and the Way Forward. Educational Research, 3, 429-435.

[2] Federal Republic of Nigeria (2004) National Policy on Education. NERDC, Lagos.

[3] Ejima, O.S. (2012) Teacher Professional Development in the 21st Century Nigeria: The Journey, the Potholes and the Patches. Global Voice of Educators, 1, 1-6.

[4] Oluremi, O.F. (2013) Enhancing Educational Effectiveness in Nigeria through Teacher's Professional Development. European Scientific Journal, 9, 422-431.

[5] Afe, J.O. (2002) Reflections on Becoming a Teacher and the Challenges of Teacher Education. An Inaugural Lecture Series 64. University of Benin, Benin City.

[6] Olagunju, O. (2012) Corruption Control in Nigeria: Holistic Approach. Advances in Arts, Social Sciences and Education Research, 2, 76-84.

[7] Adeyemo, S.A. (2012) Background and Classroom Correlates of Students' Achievement in Physics. International Journal of Educational Research and Technology, 1, 25-34.

[8] Olufunke, B.T. (2012) Effect of Availability and Utilization of Physics Laboratory Equipment on Students’ Academic Achievement in Senior Secondary School Physics. World Journal of Education, 2, 1-7. http://dx.doi.org/10.5430/wje.v2n5p1 
[9] Ajileye, O.O. (2006) Towards Effective Science Education: Issues in Universal Basic Education (U.B.E) Programme. Journal of Sports Management and Educational Research, 1, 337.

[10] Thomas, O.O. and Isaac, O.O. (2013) Assessing the Relative Effectiveness of the Three Teaching Methods in the Measurement of Students' Performance in Physics. International Journal of Material, Methods and Technologies, 1, $116-125$

[11] Owolabi, O.T. and Adedayo, J.O. (2012) Effect of Teacher's Qualification on the Performance of Senior Secondary School Physics Students: Implication on Technology in Nigeria. English Language Teaching, 5, 72-75.

[12] Akinsolu, A.O. (2010) Teachers and Students’ Academic Performance in Nigerian Secondary Schools: Implications for Planning. Florida Journal of Educational Administration \& Policy, 3, 86-103.

[13] Aina, J.K. and Akintunde, Z.T. (2013) Repositioning Science Education in Nigerian Colleges of Education through Public-Private Partnership (PPP). Science Journal of Education, 1, 64-67. http://dx.doi.org/10.11648/j.sjedu.20130105.13

[14] Akinbote, O. (2007) Problems of Teacher Education for Primary Schools in Nigeria: Beyond Curriculum Design and Implementation. Essays in Education, 22, 4-11.

[15] Obodo, G.C. (1990) Teacher Effectiveness as an Indicator of Quality Education. APGEN Mnonograph Series, Vol. 1, No. 1, Totan Publishers Ltd., Owerri.

[16] Cogill, J. (2009) Pedagogy and Models of Teacher Knowledge. www.juliecogill.com

[17] Aliyu, U.A., Yashe, A. and Adeyeye, A.C. (2013) Effect of Teachers' Qualifications on Performance in Further Mathematics among Secondary School Students. Mathematical Theory and Modeling, 3, 140-146.

[18] Shamim, M., Rashid, T. and Rashid, R. (2013) Students' Academic Performance in Physics Correlates the Experience of Teachers in Higher Secondary Schools of Jammu and Kashmir State. International Journal of Current Research, 5, 201-204.

[19] Fareo, D.O. (2013) Professional Development of Teachers in Africa: A Case Study of Nigeria. The African Symposium: An Online Journal of the African Educational Research Network, 13, 63-68.

[20] Agharuwhe, A.A. (2013) Effects of Teachers’ Effectiveness on Students’ Academic Performance in Public Secondary Schools; Delta State-Nigeria. Journal of Educational and Social Research, 3, 105-111.

[21] Aina, J.K. (2013) Effective Teaching and Learning in Science Education through Information and Communication Technology [ICT]. IOSR Journal of Research and Method in Education, 2, 43-47. http://dx.doi.org/10.9790/7388-0254347

[22] Aina, J.K. (2013) Importance of Science Education to National Development and Problems Militating against Its Development. American Journal of Educational Research, 1, 225-229. http://dx.doi.org/10.12691/education-1-7-2

[23] Adeoti, V. (2012) Challenges of Nigeria's Education System. http://www.thetidenewsonline.com/2012/09/09/challenges-of-nigeria's-education-system/

[24] Abdulahi, A. (2007) Functional Science, Technology and Mathematics Education for National Economic Empowerment and Development. Speech Delivered at the School of Science National Conference Held at Federal College of Education, Zaria.

[25] Omorogbe, E. and Ewansiha, J.C. (2013) The Challenge of Effective Science Teaching in Nigerian Secondary Schools. Academic Journal of Interdisciplinary Studies, 2, 181-188.

[26] Odia, L.O. and Omofonmwan, S.I. (2007) Educational System in Nigeria Problems and Prospects. Journal of Social Science, 14, 81-86.

[27] Akinola, B.M.A. (2006) Causes of Mass Failure in Senior Secondary School Chemistry in Ijebu East Local Government Area of Ogun State. Oro Science Educational Journal, 4, 19-26.

[28] Ojo, M.O. (2001) Problems of Teaching Science and Mathematics in Nigeria. The Train-The Trainers Workshop for Science and Mathematics Teachers in Colleges of Education in Six Geo-Political Zone of Nigeria, 30 November 2001, Kotangora, 1-10.

[29] Musasia, A.M., Abacha, O.A. and Biyoyo, M.E. (2012) Effect of Practical Work in Physics on Girls’ Performance, Attitude Change and Skills Acquisition in the Form Two-Form Three Secondary Schools' Transition in Kenya. International Journal of Humanities and Social Sciences, 2, 151-166. 